\title{
Differential tending of worker and drone larvae of the honey bee, Apis mellifera, during the 60 hours prior to cell capping
}

\author{
Nicholas W. CALDERONE*, L.P.S. KUENEN** \\ Department of Entomology Cornell University Ithaca, NY 14853, USA
}

(Received 25 March 2002; revised 26 February 2003; accepted 13 March 2003)

\begin{abstract}
Varroa destructor is a parasitic mite of A. mellifera. Female mites reproduce on both drone and worker brood; but they are found 5-9 times more often on drone brood. We examined larval tending by brood nest bees to determine if this behavior could provide an explanation for these differences. We observed workers tending worker and drone larvae in three observation colonies commencing $60 \mathrm{~h}$ prior to the completion of cell capping, an interval that includes the susceptible periods of both types of brood. Workers invested 2.78 times more time tending drone larvae than worker larvae, a difference due primarily to a greater number of tending acts directed towards drone brood. This finding demonstrates that phoretic mites may have more opportunity to enter drone brood. The 2.78 fold difference in time tending larvae combined with the previously reported 2-4-fold differences in the lengths of the periods when cells are capped could explain a 5.56-11.12 fold difference in mite levels in worker and drone brood, similar to 'previously' reported differences.
\end{abstract}

\section{Varroa destructor / Apis mellifera / nurse bee / cell capping}

\section{INTRODUCTION}

Varroa destructor Anderson and Trueman (Anderson and Trueman, 2000) is a parasitic mite that reproduces on the immature stages of its host, A. mellifera L. (reviewed in De Jong et al., 1982; De Jong, 1990). Mites reproducing on drone brood average 2.2-2.6 female offspring per host, while those reproducing on worker brood average 1.3-1.4 offspring (Schulz, 1984; Fuchs and Langenbach, 1989). Not surprisingly, mite levels tend to be higher in drone brood than worker brood, with average differences ranging from 5-9-fold (reviewed in Fries et al., 1994; Calis et al., 1999; Calderone and Kuenen, 2001).

Differential reproduction provides an evolutionary explanation for the drone-biased distribution of mites; however, the proximate mechanisms responsible for this pattern are not well understood. The observed distribution of mites is thought to be due to two factors: (1) a 2-4-fold difference in the lengths of the periods during which larvae are susceptible to mite invasion, and (2) differences in the rates at which mites enter host cells. Mites enter drone brood starting $40-60 \mathrm{~h}$ before capping is completed, but begin to enter worker brood only $15-30 \mathrm{~h}$ before capping is completed (Ifantidis, 1988; Fuchs and Muller, 1988; Boot et al., 1991, 1992). This difference may be a consequence of differences in host chemistries (Le Conte et al., 1989; Trouiller et al., 1991, 1992) or a result of physical factors (De Ruijter and Calis, 1988; De Jong and Morse, 1988; Goetz and Koeniger, 1993; Boot et al., 1995; Kuenen and Calderone, 2000).

The difference in the lengths of the susceptible periods accounts for only a 2-4 fold difference in mite levels, less than

\footnotetext{
* Corresponding author: nwc4@ cornell.edu

** Current address: USDA, ARS, SJVASC 9611 S. Riverbend Ave. Parlier, CA 93648, USA.
} 
typically reported. Therefore, there must also be a difference in the rate at which mites enter worker and drone cells. One mechanism explains differential rates of entry based on differences in levels of putative attractants produced by worker and drone larvae (Le Conte et al., 1989; Trouiller et al., 1991, 1992). Differences in the size of the openings of worker and drone cells may also provide mites with greater opportunity to enter drone cells (Boot et al., 1995).

In this study, we examined larval tending by brood nest bees to determine if this behavior could provide a mechanism to account for the drone-biased distribution of mites. Since drone larvae weigh about 2.47 times as much as worker larvae at capping (Jay, 1963; Winston, 1987), they presumably require more food. This suggests that brood nest bees may spend more time tending drone larvae than worker larvae (Martin, 1998). If true, this would bring phoretic female mites into proximity to drone brood more often than to worker brood, and that could provide a nonchemical mechanism for differential rates of mite entry into the two types of brood.

\section{MATERIALS AND METHODS}

We observed worker bees tending same-age worker and drone larvae in each of three unrelated colonies during the $60 \mathrm{~h}$ prior to cell capping. Larvae were reared in mosaic combs constructed by removing $25 \mathrm{~cm}^{2}$ sections from worker combs and replacing them with equivalent sections of drone comb. Eggs were obtained by caging the queen in each colony for $12 \mathrm{~h}$ on a mosaic comb. Then, the colonies were transferred to four-frame observation hives (Gary and Lorenzen, 1976) maintained in a temperature-controlled, observation-hive shelter (Rothenbuhler et al., 1968). Each colony consisted of about $8000-10000$ adult workers, a queen and an unknown number of adult drones.

We randomly selected 6 workers and 6 drones in each colony that were reared to the capped stage and then observed tending behavior for each selected cell at 60, 54, 48, 42, 36, 30, 24, 18, 12 and $6 \mathrm{~h}$ prior to the completion of capping, a period that encompasses the susceptible periods of both worker and drone brood. Tending behavior in each colony was recorded with a Microimage Video Systems video camera (A206 AutomatiCam) connected to a Sony VCR (SVO $9500 \mathrm{MD}$ ) and viewed on a Sony monitor (PVM-1343 MD). The test sections in each hive were recorded four times daily for $20 \mathrm{~min}$ per observation period starting when individuals were still in the egg stage. Recordings started at $24.00 \mathrm{~h}$, $6.00 \mathrm{~h}, 12.00 \mathrm{~h}$ and $18.00 \mathrm{~h}$ each day.

We defined four tending acts: act $1-$ worker bee inserts its head or part of its head into a cell; act 2 worker bee inserts its head and part or all of its thorax into a cell; act 3 - worker bee inserts its head, thorax and part of its abdomen into a cell; and act 4 - worker bee manipulates or adds wax to the rim or capping of the cell. During each $20 \mathrm{~min}$ period, we recorded the starting and ending times for each occurrence of each act and the identity of the larva being tended. Because we were interested only in characterizing the proximity of mites to brood cells, our classification of acts 1, 2 and 3 does not distinguish between feeding and non-feeding behavior.

\subsection{Analysis of means}

We analyzed (1) the number of times each act was performed per larva per period, (2) the duration of individual occurrences of each act, and (3) the cumulative amount of time each act was performed per larva per period. We used a randomized block model with repeated measures analysis of variance with larval sex, hours before capping completed (period), and their interaction modeled as fixed effects. Colony, individual larva nested within colony, and their interactions with fixed effects were modeled as random effects. Data were transformed using the square root function to achieve homogeneous variances. The analyses for act 4 were restricted to data collected between $6 \mathrm{~h}$ and $24 \mathrm{~h}$ prior to the completion of capping due to the small number of observations at other times. We also calculated the ratio of the average cumulative time invested tending drone larvae to the corresponding value for worker larvae for each act.

\subsection{Analysis of frequencies for wax working events}

Our observations allowed us to glean a preliminary look at the capping behavior of workers towards worker and drone larvae. Because (1) we observed equal numbers of worker and drone larvae in each hive during each period, (2) each larva was observed for the same amount of time, and (3) our video analysis allowed us to view all larvae during the same time periods, we were able to directly compare the frequencies at which act 4 was performed on worker and drone brood. We used the Goodness-of-Fit test to test the hypothesis that there was no significant difference in the total number of times that worker bees engaged in wax-working behavior with worker and drone larvae. We pooled 
data from all three colonies and analyzed data from each of the 10 observation periods separately.

\section{RESULTS}

\subsection{Analysis of means}

Results from the statistical analyses are presented in Table I. A summary of main effects (ls mean $\pm \mathrm{SE}$ ) is presented below. We report period effects, but we did not perform a mean separation analysis for that effect because our focus was on differences between worker and drone larvae within each period. The general trend over time for each act can be gleaned from each graph.

\subsubsection{Average number of occurrences of each act}

The average number of times acts 1, 2 and 3 were performed per larva per $20 \mathrm{~min}$ observation period are shown in Figure 1. The average number of times workers were seen to perform act 1 in a period was $18.35 \pm 0.67$ per drone larva and $9.93 \pm 0.67$ per worker larva $(P<0.0001)$. Differences between periods $(P=0.0006)$ and the interaction between larval sex and period $(P<0.0001)$ were significant. Mean separation tests (TukeyKramer) revealed that larval sex was significant in all periods except at $6 \mathrm{~h}$.

The average number of times workers were seen to perform act 2 in a period was $22.99 \pm$ 1.77 per drone larva and $5.21 \pm 1.78$ per worker larva $(P<0.0001)$. Differences between periods $(P<0.0001)$ and the interaction between larval sex and period $(P<$ $0.0001)$ were significant. Mean separation tests revealed that larval sex was significant during all periods. The average number of times workers performed act 3 in a period was $1.98 \pm 0.87$ per drone larva and $1.38 \pm 0.85$ per worker larva $(P=0.1553)$. Differences between periods $(P=0.0005)$ and the interaction between larval sex and period $(P=$ $0.0005)$ were significant. Mean separation tests revealed that larval sex was significant only at $60 \mathrm{~h}$.

For act 4, the analysis was restricted to 6 , 12,18 and $24 \mathrm{~h}$ before capping was complete due to the small number of observations
Table I. Results of ANOVA's for the analysis of means for each variable $(\mathrm{df}=$ numerator, denominator degrees of freedom).

\begin{tabular}{llccc}
\hline ACT & \multicolumn{1}{c}{ EFFECT } & $\boldsymbol{F}$-value & $(\mathbf{d f})$ & $\boldsymbol{P}$-value \\
\hline \multicolumn{4}{l}{ Average number of occurrences of each act } \\
\hline 1 & SEX & 89.13 & $(1,32)$ & 0.0001 \\
& PERIOD & 3.38 & $(9,298)$ & 0.0006 \\
& SEX*PERIOD & 3.87 & $(9,298)$ & 0.0001 \\
2 & SEX & 320.72 & $(1,32)$ & 0.0001 \\
& PERIOD & 8.14 & $(9,298)$ & 0.0001 \\
& SEX*PERIOD & 4.16 & $(9,298)$ & 0.0001 \\
3 & SEX & 2.12 & $(1,32)$ & 0.1553 \\
& PERIOD & 3.57 & $(9,1274)$ & 0.0005 \\
& SEX*PERIOD & 3.79 & $(8,127)$ & 0.0005 \\
& & & & \\
4 & SEX & 1.18 & $(1,28)$ & 0.2863 \\
& PERIOD & 2.61 & $(9,68)$ & 0.0119 \\
& SEX*PERIOD & 0.28 & $(6,68)$ & 0.9439
\end{tabular}

Average duration of individual occurrences of each act:

\begin{tabular}{|c|c|c|c|c|}
\hline \multirow[t]{3}{*}{1} & SEX & 23.49 & $(1,32)$ & 0.0001 \\
\hline & PERIOD & 7.80 & $(9,298)$ & 0.0001 \\
\hline & SEX*PERIOD & 3.59 & $(9,298)$ & 0.0003 \\
\hline \multirow[t]{3}{*}{2} & SEX & 0.96 & $(1,32)$ & 0.3337 \\
\hline & PERIOD & 5.47 & $(9,286)$ & 0.0001 \\
\hline & SEX*PERIOD & 5.82 & $(9,286)$ & 0.0001 \\
\hline \multirow[t]{3}{*}{3} & SEX & 1.31 & $(1,32)$ & 0.2610 \\
\hline & PERIOD & 0.68 & $(9,127)$ & 0.7253 \\
\hline & SEX*PERIOD & 1.57 & $(8,127)$ & 0.1387 \\
\hline \multirow[t]{3}{*}{4} & SEX & 0.91 & $(1,28)$ & 0.3495 \\
\hline & PERIOD & 1.90 & $(9,68)$ & 0.0659 \\
\hline & SEX*PERIOD & 0.31 & $(6,68)$ & 0.9304 \\
\hline \multicolumn{5}{|c|}{ Cumulative amount of time for each act: } \\
\hline \multirow[t]{3}{*}{1} & SEX & 100.80 & $(1,32)$ & 0.0001 \\
\hline & PERIOD & 7.54 & $(9,286)$ & 0.0001 \\
\hline & SEX*PERIOD & 2.53 & $(9,286)$ & 0.0082 \\
\hline \multirow[t]{3}{*}{2} & SEX & 159.52 & $(1,32)$ & 0.0001 \\
\hline & PERIOD & 11.66 & $(9,286)$ & 0.0001 \\
\hline & SEX*PERIOD & 5.41 & $(9,286)$ & 0.0001 \\
\hline \multirow[t]{3}{*}{3} & SEX & 0.04 & $(1,32)$ & 0.8519 \\
\hline & PERIOD & 2.36 & $(9,127)$ & 0.0171 \\
\hline & SEX*PERIOD & 2.14 & $(8,127)$ & 0.0366 \\
\hline \multirow[t]{3}{*}{4} & SEX & 1.90 & $(1,28)$ & 0.1786 \\
\hline & PERIOD & 3.18 & $(9,68)$ & 0.0022 \\
\hline & SEX*PERIOD & 0.39 & $(6,68)$ & 0.8800 \\
\hline
\end{tabular}




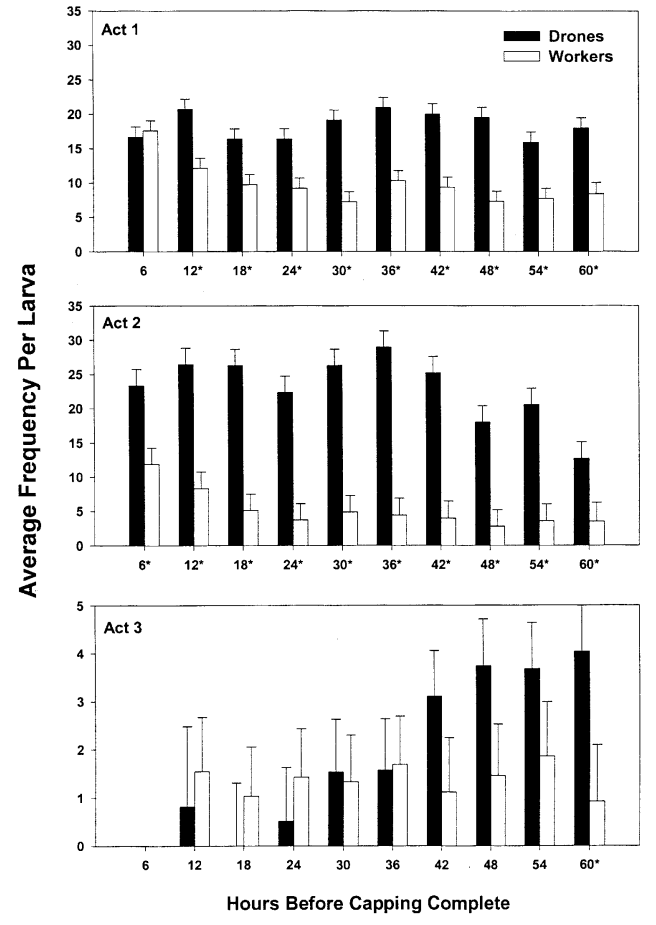

Figure 1. The average number of times acts 1,2 and 3 (ls mean $\pm \mathrm{SE}$ ) were performed on worker and drone larvae during each of the $20 \mathrm{~min}$ observation periods. An ' $*$ ' indicates that the worker and drone values for that period are significantly different (Tukey-Kramer, $P<0.05$ ). The graphs have different scales.

during the other periods. Data for act 4 are presented in Figure 2A. The average number of times act 4 was observed in a period was $4.21 \pm 0.65$ per drone larva and $2.17 \pm 1.39$ per worker larva $(P<0.2863)$. Differences between periods $(P<0.0119)$ were significant, with greater numbers of acts observed closer to the time that capping was complete. The interaction between larval sex and period was not significant $(P=0.9439)$.

\subsubsection{Average duration of individual occurrences of each act}

The average duration of individual occurrences of acts 1, 2, and 3 during each of the observation periods are shown in Figure 3. The average duration of act 1 was $0.79 \pm$ $0.06 \mathrm{~s}$ per drone larva and $0.63 \pm 0.06 \mathrm{~s}$ per worker larva $(P<0.0001)$. Differences
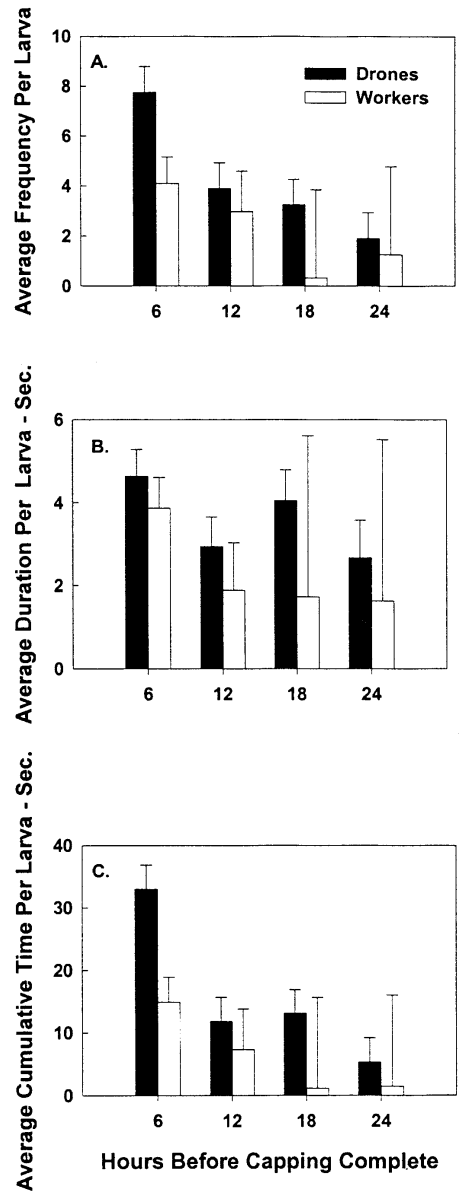

Figure 2. Results of analysis of each variable for act 4 , wax working. (A) the average number of times (ls mean \pm SE) act 4 was observed to be performed during the last 4 observation periods; (B) the average duration of each occurrence of act 4 during the last 4 observation periods; and (C) the cumulative amount of time for act 4 during the last 4 observation periods. The graphs have different scales.

between periods $(P<0.0001)$ and the interaction between larval sex and period $(P=$ 0.0003 ) were significant. Mean separation tests revealed a significant effect of larval sex at 12,18 and $30 \mathrm{~h}$.

The average duration of act 2 was $5.62 \pm$ $0.41 \mathrm{~s}$ per drone larva and $6.58 \pm 0.61 \mathrm{~s}$ per worker larva $(P=0.3377)$. Differences between periods $(P<0.0001)$ and the interaction between larval sex and period $(P<$ $0.0001)$ were significant. Mean separation 


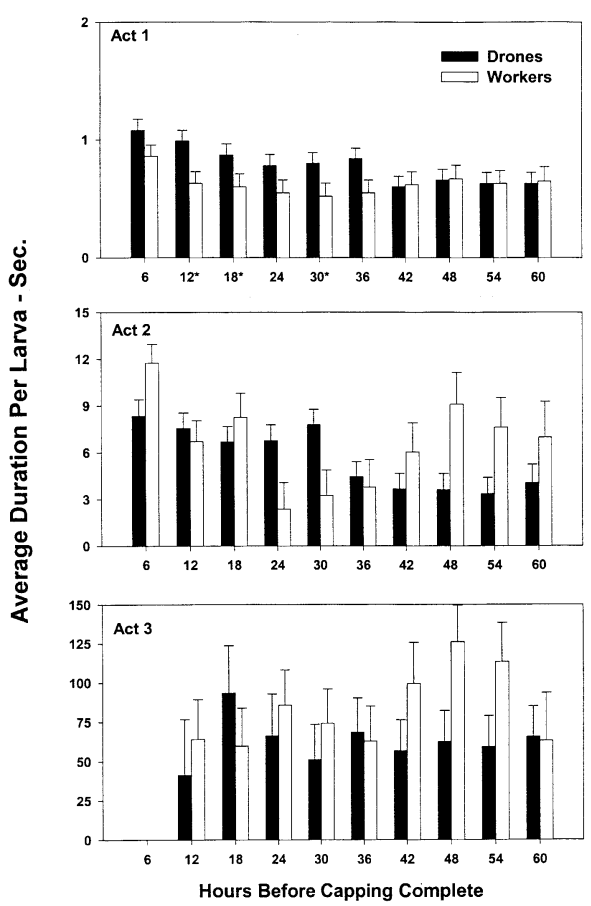

Figure 3. The average duration (ls mean $\pm \mathrm{SE}$ ) of acts 1, 2 and 3 for worker and drone larvae during each $20 \mathrm{~min}$ observation period. The graphs have different scales.

tests did not reveal a significant effect of larval sex during any period. The average duration of act 3 was $62.75 \pm 18.88$ s per drone larva and $83.75 \pm 18.75 \mathrm{~s}$ per worker larva $(P=0.2610)$. Differences between periods $(P=0.7253)$ and the interaction between larval sex and period $(P=0.1387)$ were not significant.

Data for the average duration of act 4 are shown in Figure 2B. The average duration of act 4 was $3.58 \pm 0.06 \mathrm{~s}$ per drone larva and $2.28 \pm 1.47 \mathrm{~s}$ per worker larva $(P=0.3495)$. Differences between periods $(P=0.0659)$ and the interaction between larval sex and period $(P=0.9304)$ were not significant.

\subsubsection{Cumulative amount of time for each act}

The average cumulative times for acts 1,2 and 3 per larva during each period are shown in Figure 4. The average cumulative time of act 1 in a period was $14.24 \pm 0.98 \mathrm{~s}$ per drone larva and $6.55 \pm 0.99 \mathrm{~s}$ per worker larva

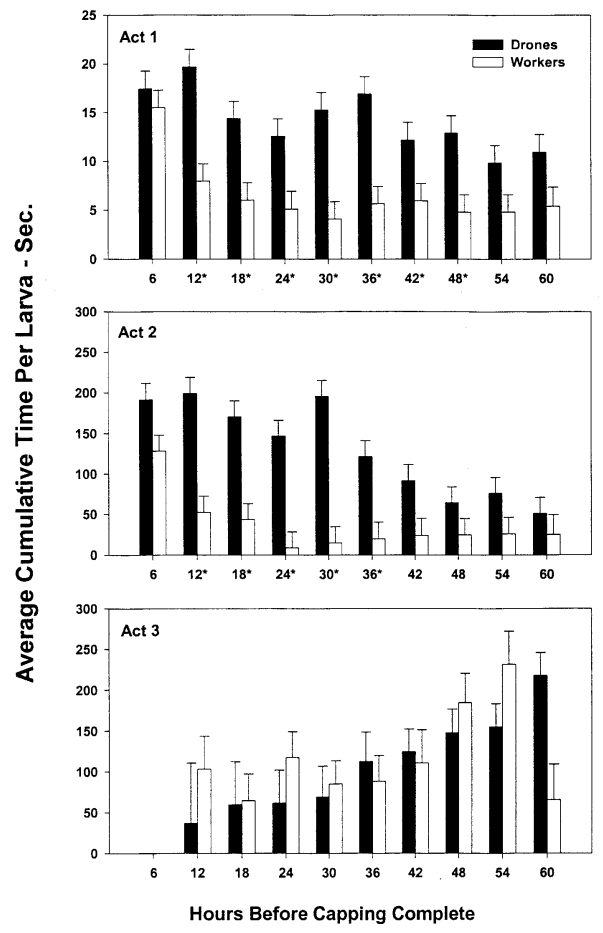

Figure 4. The average cumulative amount of time (ls mean \pm SE) for acts 1, 2 and 3 during each of the 20 min observation periods. An '*' indicates that the worker and drone values for that period are significantly different based on mean separation techniques (Tukey-Kramer, $P<0.05$ ). The graphs have different scales.

$(P<0.0001)$. Differences between periods $(P<0.0001)$ and the interaction between larval sex and period $(P=0.0082)$ were significant. Mean separation tests revealed a significant effect of larval sex for all periods except at 6,54 and $60 \mathrm{~h}$.

The average cumulative time for act 2 in a period was $130.88 \pm 9.38 \mathrm{~s}$ per drone larva and $36.77 \pm 9.58 \mathrm{~s}$ per worker larva $(P<0.0001)$. Differences between periods $(P<0.0001)$ and the interaction between larval sex and period $(P<0.0001)$ were significant. Mean separation tests revealed a significant effect of larval sex at 12, 18, 24, 30 and $36 \mathrm{~h}$. The average total cumulative time for act 3 in a period was $116.85 \pm 16.82 \mathrm{~s}$ per drone larva and $109.37 \pm 18.47 \mathrm{~s}$ per worker larva $(P=$ $0.8519)$. Differences between periods $(P=$ 0.0171 ) and the interaction between larval sex 
and period $(P=0.0366)$ were significant. Mean separation tests did not reveal any additional significant differences.

Data for the average cumulative time for act 4 are shown in Figure $2 \mathrm{C}$. The average cumulative time for act 4 in a period was $15.79 \pm 1.93 \mathrm{~s}$ per drone larva and $6.18 \pm$ 5.48 s per worker larva $(P=0.1786)$. Differences between periods $(P=0.0022)$ were significant, but not the interaction between larval sex and period $(P=0.8800)$.

\subsection{Investment ratios for worker and drone brood}

We calculated an average investment ratio from the cumulative amount of time that workers were observed to engage in each act with worker and drone larvae. For act 1, the ratio of the average cumulative time invested per drone larva to the corresponding value for workers was 2.17 . For act 2 , the corresponding ratio was 3.56. For act 3 , the ratio was 1.07 . For act 4 , the ratio was 2.56 . We calculated an overall ratio of time invested in drone and worker brood by multiplying the investment ratio for each act by the relative number of times that act was observed and summing the products. Overall, workers invested 2.78 times more time tending drone brood than they did tending worker brood during the $60 \mathrm{~h}$ prior to cell capping.

\subsection{Analysis of frequencies for wax-working events}

Over all periods and colonies, act 4 was performed 335 times on drone brood and 79 times on workers (Fig. 5). Goodness of fit tests revealed significant differences in overall frequencies at each observation period except 54 and 60 hours before capping was completed.

\section{DISCUSSION}

Workers invested more time tending drone larvae than worker larvae. This difference was due primarily to a greater number of each of the four acts being directed towards drone brood than towards worker brood. Additionally, the average duration of act 1 was approximately $25 \%$ greater for drone larvae.

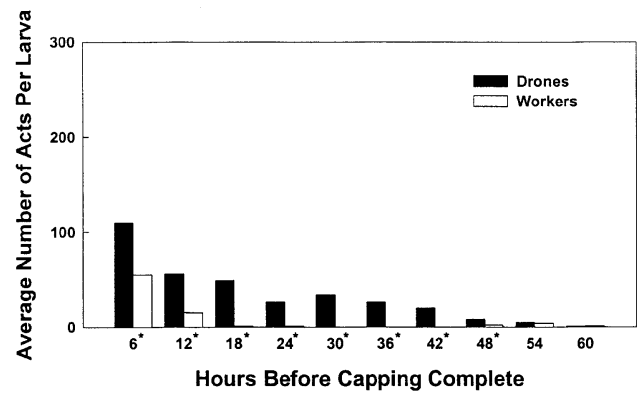

Figure 5. The total number of times act 4 (wax working) was observed to be performed on worker and drone larvae during each 20 min observation period. An ' $*$ ' indicates that the worker and drone values for the given act in the given period are significantly different based on a Goodness-of-Fit Test $(P<0.0001)$.

Averaged over all acts, the investment ratio for time spent tending larvae was 2.78 greater for drone larvae than for worker larvae. Because tending behavior brings mites into proximity with prospective immature hosts, this difference may provide mites with increased opportunities to enter drone brood.

We also found differences in the timing of cell capping. Workers began capping drone cells at $48 \mathrm{~h}$, whereas they began to cap worker cells at 12-24 h; therefore, the length of the periods when workers cap drone and worker cells differ by a factor of 4 (if initiated at $12 \mathrm{~h}$ ) or 2 (if initiated at $24 \mathrm{~h}$ ). If the raised cell walls that occur during capping act as a cue for a mite to enter a cell (Kuenen and Calderone, 2000), drone brood would be susceptible 24 times as long as worker brood.

\section{Models for host acquisition}

One explanation for the biased distribution of mites is the chemical attractant hypothesis (Le Conte et al., 1989). Accordingly, mite levels are higher in drone brood because they produce greater quantities of the putative attractants methyl palmitate, ethyl palmitate and methyl linolenate, which results in a greater rate of mite entry, and because they produce elevated levels of these compounds over a longer period of time, which results in a longer susceptible period (Trouiller et al., 1991, 1992). However, other studies suggest 
that mites do not use these substances to identify a host's sex (Rickli et al., 1992, 1994; Boot, 1994; Donzé et al., 1998; Calderone and Lin, 2001).

Alternatives to the chemical hypothesis are based on physical factors. Goetz and Koeniger (1993) found a correlation between the distance from a worker larva to the cell rim (larva-to-rim) and the initiation of mite entry into brood cells. Mites entered cells once the larva-to-rim distance decreased to ca. 7.0$7.5 \mathrm{~mm}$ as the larvae grew larger/upward in the cells. Boot et al. (1995) conducted a similar study and reported that the infestation of worker cells increased at a constant rate over time once this critical distance was reached, even as the larva-to-rim distance continued to decrease due to larval growth. According to this critical distance hypothesis, drone larvae have a longer susceptible period than worker larvae because they achieve the critical distance sooner.

Kuenen and Calderone (2000) proposed an alternative physical model based on their finding that elevated cell walls that occur during capping serve as a stimulus triggering mite entry into brood cells. Their model explains differences in the susceptible periods of worker and drone brood as a consequence of the capping process being initiated earlier for drone brood than for worker brood.

Our data on tending behavior provide mechanisms to explain both the greater lengths of the susceptible period for drones and the greater rate of entry by mites into drone cells. If the elevation of the cell wall that occurs as workers begin to cap a cell provides the stimulus for mites to enter a cell (De Ruijter and Calis, 1988; Kuenen and Calderone, 2000), then drone brood will be susceptible to mite entry 2-4 times longer than worker brood. If the rate of entry into cells is directly proportional to the amount of time workers spend tending a brood cell, then the overall 2.78 fold difference in total time spent tending drone and worker larvae could explain a similar difference in entry rates. Together, differences in capping and tending behavior could explain a 5.56-11.12 fold difference in mite levels in drone and worker brood, similar to the range reported in the literature. Of course, differences in time spent tending could be combined with either of the other mechanisms that explain differences in the lengths of the susceptible periods (Trouiller et al., 1991, 1992; Goetz and Koeniger, 1993); however, we feel that the elevated cell wall currently provides the best explanation for differences in susceptible periods. We hypothesize that physical cell factors (Kuenen and Calderone, 2000) and larval tending times are the primary factors determining cell entry by adult female Varroa mites and that chemical substances from larvae, cocoons and brood food lead to retention and orientation of mites once they are in the cell (Donzé et al., 1998; Calderone and Lin, 2001). Further studies are required to confirm this hypothesis.

\section{ACKNOWLEDGEMENTS}

We thank Cole Gilbert for valuable discussion, Rick Turcotte for valuable technical assistance, and two anonymous reviewers for valuable comments on the manuscript. This research was supported in part by grants from USDA-NRICGP (\#9601786, 9802583) and the New York State Dept. of Agriculture and Markets (\#C970001) and by a Hatch grant (NYC \#139-6431) to NWC.

Résumé - Des soins différents sont donnés aux larves d'ouvrières et aux larves de mâles de l'Abeille domestique, Apis mellifera, au cours des 60 heures précédant l'operculation. Les femelles de l'acarien parasite Varroa destructor se reproduisent sur le couvain de mâles et sur celui d'ouvrières, mais on les trouve 5 à 9 fois plus souvent sur le couvain de mâles. Ce chiffre peut s'expliquer pour un facteur de 2 à 4 par les différences dans la période où les acariens sont susceptibles de pénétrer dans les cellules de larves. On considère que le reste de la disparité est dû aux différences de taux de pénétration des acariens en fonction du type de cellule de couvain.

Nous avons étudié les soins aux larves donnés par les nourrices pour déterminer si ce comportement pouvait rendre compte des taux plus élevés de $V$. destructor dans le couvain de mâles. Nous avons observé, au cours des 60 heures précédant l'operculation, des ouvrières donnant des soins à des larves d'ouvrières et de mâles de même âge dans trois colonies non apparentées. Dans chaque colonie, les œufs ont été obtenus en enfermant la reine durant $12 \mathrm{~h}$ dans une cage sur un rayon mosaïque comprenant à la fois des cellules d'ouvrières et des cellules de mâles. Les reines ont été libérées, puis les colonies transférées dans des ruches d'observation à quatre cadres. Chaque colonie comprenait environ 8000 à 10000 ouvrières adultes, une reine et un nombre inconnu de mâles adultes. 
Le comportement de soins a été enregistré avec une caméra vidéo. Les sections testées dans chaque ruche ont été enregistrées quatre fois par jour durant 20 min dès le stade de l'œuf. Dans chaque colonie, nous avons sélectionné au hasard six ouvrières et six mâles qui ont été élevés jusqu'au stade operculé puis, pour chaque cellule choisie, le comportement de soins a été observé à $60,54,48,42,36,30,24$, 12 et $6 \mathrm{~h}$ avant l'operculation complète, période qui entoure les périodes sensibles mentionnées pour le couvain d'ouvrières et celui de mâles.

Nous avons défini quatre actes de soins : acte (1) l'ouvrière insère tout ou partie de sa tête dans une cellule ; acte (2) l'ouvrière insère sa tête et tout ou partie de son thorax; acte (3) l'ouvrière insère sa tête, son thorax et une partie de son abdomen; acte (4) l'ouvrière manipule ou ajoute de la cire au bord ou à l'opercule de la cellule. Durant chaque période de $20 \mathrm{~min}$ nous avons enregistré l'heure du début et de la fin pour chaque occurrence de chaque acte ainsi que l'identité de la larve recevant les soins. Parce que nous cherchions seulement à caractériser la proximité des acariens par rapport aux cellules de couvain, notre classification des actes 1,2 et 3 ne fait pas la distinction entre comportement alimentaire et non alimentaire.

Les ouvrières ont investi 2,78 fois plus de temps dans les soins aux larves de mâles que dans les soins aux larves d'ouvrières. Cette différence est due en premier lieu au plus grand nombre d'actes de soins à l'intention du couvain de mâles, résultat qui prouve que les acariens phorétiques sont susceptibles d'avoir plus d'occasions de pénétrer dans le couvain de mâles. Nous avons aussi trouvé que les ouvrières commençaient à manipuler la cire autour de l'ouverture des cellules de mâles 48 h avant l'operculation complète, tandis que pour les cellules d'ouvrières elles ne démarraient cette activité que 12 à $24 \mathrm{~h}$ avant l'operculation, soit une différence de 2 à 4 fois. Les études antérieures avaient trouvé que l'élévation de la paroi de la cellule qui a lieu au cours de l'operculation agit comme un stimulus qui incite les acariens à pénétrer dans la cellule de couvain. La différence de 2,78 fois dans le temps passé à donner des soins aux larves combinée à la différence de 2 à 4 fois dans la durée des périodes durant lesquelles les cellules sont operculées expliquent une différence de 5,56 à 11,12 fois dans les taux d'infestation par $V$. destructor des cellules d'ouvrières et de mâles, ce qui est comparable à la gamme des différences mentionnées dans les études de terrain.

Varroa destructor / nourrice / operculation / soins aux larves

Zusammenfassung - Unterschiedliche Pflege von Arbeiterinnen- und Drohnenlarven der Honigbiene, Apis mellifera L., ab 60 Stunden vor dem Verdeckeln der Zellen. Weibchen der parasitischen Milbe Varroa destructor vermehren sich sowohl auf Drohnen- wie auf Arbeiterinnenbrut; aber sie werden 5-9 mal häufiger in Drohnenbrut gefunden. Ein Unterschied in der Häufigkeit von 2-4 soll auf der unterschiedlichen Dauer beruhen, in der Milben die Larven befallen können. Ein weiterer Unterschied soll in der Anzahl bestehen, in denen die Milben in die Brutzellen eindringen. Wir untersuchten die Pflege der Larven durch Ammenbienen um festzustellen, ob es in ihrem Verhalten einen Mechanismus gibt, der zum höheren Befall von $V$. destructor in Drohnenbrut führt. Wir beobachteten Arbeiterinnen in 3 unverwandten Völkern, die Larven von Arbeiterinnen und Drohnen der gleichen Altersgruppe versorgten. Der Versuch begann 60 Stunden vor der Verdeckelung. Datierte Eier wurden durch Käfigen der Königinnen über eine Dauer von $12 \mathrm{~h}$ auf einer Wabe mit Arbeiterinnen- und Drohnenzellen erhalten. Nach der Freilassung der Königinnen wurden die 3 Völker in einen Beobachtungsstock mit 4 Waben umgesetzt. Jedes Volk bestand aus etwa 8000 10000 adulten Arbeiterinnen, einer Königin und einer unbekannten Zahl von adulten Drohnen.

Das Pflegeverhalten wurde in jedem Volk mit einer Videokamera aufgenommen. Das Testwabenstück wurde jeweils 4 mal täglich 20 Minuten lang aufgenommen. Mit den Aufnahmen wurde bereits im Eistadium begonnen. Wir suchten uns zufällig in jedem Volk 6 Arbeiterinnen und Drohnen aus, die bis zur Verdeckelung gepflegt wurden und notierten das Pflegeverhalten für jede dieser Zellen $60,54,48,42,36,30,24,18,12$ und $6 \mathrm{~h}$ vor der Fertigstellung des Zelldeckels. Diese Zeitspanne schließt die entscheidende Periode ein, in der der Befall sowohl der Arbeiterinnen- als auch der Drohnenlarven erfolgt.

Wir definierten 4 Arten der Pflege: 1 - die Arbeiterin steckt ihren Kopf oder einen Teil des Kopfes in die Zelle; 2 - die Arbeiterin steckt den Kopf und den Throax ganz oder teilweise in die Zelle; 3 - die Arbeiterin steckt Kopf, Thorax und einen Teil des Abdomens in die Zelle; und 4 - die Arbeiterin formt oder fügt Wachs an den oberen Rand oder an den Deckel der Zelle. Während der Dauer von 20 min notierten wir den Beginn und das Ende von jedem spezifischem Pflegeverhalten und die Identität der Larve, die gepflegt wurde.

Arbeiterinnen verbrachten 2,78 mal mehr Zeit bei einer Drohnen- als bei einer Arbeiterinnenlarve. Dieser Unterschied beruhte vor allem auf der höheren Zahl der Pflegemaßnahmen bei Drohnenbrut. Dieses Ergebnis zeigt, dass eine phoretischen Milbe häufiger die Gelegenheit hat, in die Drohnenbrut einzudringen. Außerdem stellte sich heraus, dass die Arbeiterinnen begannen, das Wachs der Drohnenzellen $48 \mathrm{~h}$ vor der vollständigen Verdeckelung zu bearbeiten, während diese Aktivität bei Arbeiterinnenzellen erst 12-24 h zuvor auftrat, ein 2 bis 4 facher Unterschied. Frühere Studien zeigten, dass die Erhöhung der Zellwände während der Verdeckelung für die Milben ein Stimulus ist, in die Zelle einzudringen. Dieser 2,78-mal größere 
Zeitunterschied bei der Larvenpflege kombiniert mit dem 2-4-mal größeren Unterschied in der Zeit bis die Zellen verdeckelt sind, könnte einen 5,5611,12-mal so großen Unterschied in der Rate des Milbenbefalls bei Arbeiterinnen- und Drohnenbrut erklären und ist vergleichbar zu den Unterschieden in der Befallsrate, die in Feldversuchen gefunden wurde.

\section{Varroa destructor / Apis mellifera / Ammenbie-} nen / Zellverdeckelung

\section{REFERENCES}

Anderson D.L., Trueman J.W.H. (2000) Varroa jacobsoni (Acari: Varroidae) is more than one species, Exp. Appl. Acarol. 24, 165-189.

Boot W.J. (1994) Methyl palmitate does not elicit invasion of honeybee brood cells by Varroa mites, Exp. Appl. Acarol. 18, 587-592.

Boot W.J., Calis J.N.M., Beetsma J. (1991) Invasion of Varroa mites into honeybee brood cells; when do brood cells attract Varroa mites? Proc. Exp. Appl. Entomol. N. E. V. Amsterdam 2, $154-156$

Boot W.J., Calis J.N.M., Beetsma J. (1992) Differential periods of Varroa mite invasion into worker and drone cells of honey bees, Exp. Appl. Acarol. 16, 295-301.

Boot W.J., Driessen R.G., Calis J.N.M., Beetsma J. (1995) Further observations on the correlation between attractiveness of honey bee brood cells to Varroa jacobsoni and the distance from larva to cell rim, Entomol. Exp. Appl. 76, 223-232.

Calderone N.W., Kuenen L.P.S. (2001) Effect of Honey Bee, Apis mellifera L. (Hymenoptera: Apidae), Colony, Cell Type and Larval Sex on Host Selection by Female Varroa destructor (Acari: Varroidae), J. Econ. Entomol. 94, 10221030.

Calderone N.W., Lin S. (2001) Arrestment activity of extracts of honey bee worker and drone larvae, cocoons and brood food on female Varroa destructor, Physiol. Entomol. 26, 241-350.

Calis J.N.M., Fries I., Ryrie S.C. (1999) Population modelling of Varroa jacobsoni Oud., Apidologie $30,2-3,111-124$.

De Jong D. (1990) Mites: Varroa and other parasites of brood, in: Morse R.A., Nowogrodzki R. (Eds.), Honey bee pests, predators, and diseases, 2nd ed., Cornell University Press, Ithaca, NY, p. 474.

De Jong D., Morse R.A., Eickwort G.C. (1982) Mite pests of honey bees, Annu. Rev. Entomol. 27, 229-252.

De Jong D., Morse R.A. (1988) Utilisation of raised brood cells of the honey bee, Apis mellifera
(Hymenoptera: Apidae), by the bee mite, Varroa jacobsoni (Acarina: Varroidae), Entomol. Gen. 14, 103-106.

De Ruijter A., Calis J. (1988) Distribution of Varroa jacobsoni female mites in honey bee worker brood cells of normal and manipulated depth (Acarina: Varroidae), Entomol. Genet. 14, 107109.

Donzé G., Schnyder-Candrian S., Bogdanov S., Diehl P.A., Guerin P.M., Kilchenman V., Monachon F. (1998) Aliphatic alcohols and aldehydes of the honeybee cocoon induce arrestment behavior in Varroa jacobsoni (Acari: Mesostigmata), an ectoparasite of Apis mellifera, Arch. Insect Physiol. Biochem. 37, 129-145.

Fries I., Camazine S., Sneyd J. (1994) Population dynamics of Varroa jacobsoni: a model and a review, Bee World 75, 5-28.

Fuchs S., Langenbach K. (1989) Multiple infestation of Apis mellifera L. brood cells and reproduction of in Varroa jacobsoni Oud., Apidologie 20, 257 266.

Fuchs S., Muller K. (1988) Invasion of honeybee brood cells by Varroa jacobsoni in relation to the age of the larvae, in: European research on Varroatosis control: Proceeding of EC Expert's Group, Bad Homburg, 15-17 October 1986, R. Cavalloro (Ed.) Brookfield, VT: Balkema, pp. 77-79.

Gary N.E., Lorenzen K. (1976) How to construct and maintain an observation bee hive, University of California, Division of Agricultural Sciences, Cooperative Extension Leaflet 2853.

Goetz B., Koeniger N. (1993) The distance between larva and cell opening triggers brood cell invasion by Varroa jacobsoni, Apidologie 24, 67-72.

Ifantidis M.D. (1988. Some aspects of the process of Varroa jacobsoni mite entrance into honey bee (Apis mellifera ) brood cells, Apidologie 19, 387396.

Jay S.C. (1963) The development of honeybees in their cells, J. Apic. Res. 2, 117-134.

Kuenen L.P.S., Calderone N.W. (2000) Varroa mite infestations in elevated honey bee brood cells: effects of context and caste, J. Insect Behav. 13, 201-215

Le Conte Y., Arnold G., Trouiller J., Masson C. Chappe B., Ourisson G. (1989) Attraction of the parasitic mite Varroa jacobsoni to the drone larvae of honey bees by simple aliphatic esters, Science 245, 638-639.

Martin S. (1998) A population model for the ectoparasitic mite Varroa jacobsoni in honey bee (Apis mellifera) colonies, Ecol. Model. 109, 267-281.

Rickli M., Guerin P.M., Diehl P.A. (1992) Palmitic acid released from honeybee worker larvae attracts the parasitic mite Varroa jacobsoni 
on a servosphere, Naturwissenschaften 79, 320322.

Rickli M., Diehl P.A., Guerin P.M. (1994) Cuticle alkanes of honeybee larvae mediate arrestment of bee parasite Varroa jacobsoni, J. Chem. Ecol. 20, 2437-2453.

Rothenbuhler W.C., Thompson V.C., McDermott J.J. (1968) Control of the environment of honeybee observation colonies by the use of hive-shelters and flight cages, J. Apic. Res. 7, 151-155.

Schulz A. (1984) Reproduktion und Populationsentwicklung der parasitischen Milbe Varroa jacobsoni Oud. in Abhängigkeit vom Brutzyklus ihres Wirts Apis mellifera L., Apidologie 15, 401-420.

Trouiller J., Arnold G., Le Conte Y., Masson C. (1991) Temporal pheromonal and kairomonal secretion in the brood of honeybees, Naturwissenschaften 78, 368-370.

Trouiller J., Arnold G., Chappe B., Le Conte Y., Masson C. (1992) Semiochemical basis of infestation of honey bee brood by Varroa jacobsoni, J. Chem. Ecol. 18, 2041-2053.

Winston M.L. (1987) The Biology of the Honey Bee, Harvard University Press, Cambridge, London, $281 \mathrm{p}$. 